\title{
HERBOLOGICAL CONDITION AND HERBICIDE CONTROL OF POTATO AGROPHYTOCENOSIS IN THE WESTERN PART OF UKRAINE
}

Lviv National Agrarian University, Dubliany, Ukraine

\begin{abstract}
The article presents original research on the herbicides influence on weed species and productivity of potato agrophytocenosis of Volya variety under organo-mineral and organic fertilizer systems in the western part of Ukraine.
\end{abstract}

Key words: agrophytocenosis, potato, weeds, herbicide control, tuber yield, quality.

\section{INTRODUCTION}

The analysis of the structure of categories of lands for different purposes gives grounds to believe that the problem of weeds can be taken care of by business entities and herbologists in at least $80 \%$ of the territory of Ukraine. This, in addition to agricultural land, can be the territory of settlements, industrial facilities, roads, recreational areas, forest lands and water resources. The process of intensive weed control is possible only on arable lands and under perennial fruit and berry plantations and vineyards. In most other areas, weed control efforts are much less or temporarily absent (Shuvar 2008, 2011; Manko 2009; Storchous 2010; Urbanowicz 2015; Biernacki 2018; Suchorzewski 2018; Ivashchenko 2019).

The species composition of weeds in different soil and climatic zones of Ukraine has certain features, in particular, their different requirements for growing conditions and different distribution areas of individual crops. Such weeds as Raphanus raphanistrum, Stellaria media (L.) and other moisture-loving weeds are distributed mainly in the western part of Ukraine in Polissya and in the Forest-Steppe and are almost absent in the arid zone of the Steppe.

While Acroptilon repens Pall. is distributed mainly in the northern steppe, Crimea and in the southern regions of Ukraine (Mykolayiv, Kherson, Odessa). Bromus secalinus, Camelina alyssum, Lolium remotum Schrank are distributed in zone of Polissya, where rye and flax are grown. And weeds specific to rice crops - Echinochloa phyllopogon L, Bolboschoenus maritimus $L$. are common in the Crimea and the coastal zone of southern Ukraine. However, many malicious weeds Elytrigia repens (L.), Polygonum convolvulus, Chenopodium album, Cirsium arvense are distributed almost throughout Ukraine (Ivashchenko 2004; Shuvar 2008, 2011).

Corresponding author: Ivan Shuvar, Lviv National Agrarian University, Volodymyra Velykoho 1, Dubliany, 80381 Lviv, Ukraine, e-mail: shuvaria@ukr.net 
There are 218 species of dangerous quarantine organisms in the world, 37 of which are weeds. 17 of them are already available in Ukraine. However, with the increase in the import of seeds from abroad, the risk of their entry into the country has increased many times (Grigorak 2004; Ivashenko 2006).

In order to develop effective measures for the control of non-native organisms, first of all, it is necessary to carry out an ecological and economic assessment of the impact of these plants on the environment - both on agrophytosystems and on uncultivated land. Interference of invasive organisms in semi-natural and natural cenoses causes redistribution of species in groups, disturbs the ecological balance. The negative impact of invasive plants on the current state of natural and anthropogenically transformed ecosystems, first of all, it is important to take into account for the implementation of measures to protect the whole environment, as well as ecosystems and individual species. However, the findings of changes in anthropogenically transformed, semi-natural and natural cenoses caused by the influence of non-native plants are not enough. The formation of a database on the type and degree of littering of non-agricultural lands (fallows, forest plantations, river banks, etc.), economic assessment of environmental pollution, losses and long-term risks from non-native plants is relevant (Protopopova et al. 2002).

Under conditions of contamination of sown areas and agricultural products with quarantine weeds, the market price for it is rapidly declining and the producer suffers direct losses (Zuza 2014).

The most malicious and uncommon weeds are considered quarantine and are destroyed immediately. In Ukraine, such weeds include Polygonum convolvulus, all types of Convolvulus, Ambrosia, Solanum rostratum and others (Sykalo and Chernega 2017).

An invasive species is an alien species that has become harmful due to its aggressive growth, rapid, uncontrollable distribution, replacement of aboriginal plants, and threat to natural biodiversity and natural habitats by acting as an agent for their change or degradation.

According to preliminary estimates, there are about a thousand species of foreign plants in Ukraine, including such aggressive invasive species as Ambrosia artemisiifolia L., Heracleum sosnowskyi Manden, Cenchrus paucijlorus Benth, Amorpha fruticosa and others that are already causing significant damage to the economy of Ukraine.

A well-founded division of weeds according to their harmfulness was proposed by Nikitin (1983), dividing them into three groups. To the first he included the most stable species, well adapted to existing technologies for growing crops (25-30 species). The second group consists of less common weeds that inhabit crops only in violation of agronomic requirements for growing cultivated plants in the agrocenosis (60-70 species). The third group includes unstable or insufficiently stable weeds in agrocenoses (more than 900 species).

However, this approach lacks sufficiently clear criteria for assigning certain species to certain groups. Therefore, a method of classification of weeds by their distribution has been developed, which is based on the frequency of occurrence of the species in agrocenoses and its dominance among other weed species (Table 1). 
Table 1. Criteria for determining the state of weed distribution (Gutyansky, Zuza, Fesenko)

\begin{tabular}{lcc}
\hline \multicolumn{1}{c}{ Distribution group } & Meeting frequency [\%] & Dominance [\%] \\
\hline Very common & $76-100$ & $<50$ \\
\hline Widespread & $51-75$ & $31-0$ \\
\hline Common & $26-50$ & $11-30$ \\
\hline Uncommon & $10-25$ & less than 10 \\
\hline Very uncommon & less than 10 & 0 \\
\hline
\end{tabular}

According to the results of a long-term study by Professor of the Institute of Bioenergy Crops and Sugar Beets of NAAS of Ukraine Oleksandr Ivashchenko (2019), Professor of General Agriculture of Lviv National Agrarian University Ivan Shuvar (2008, 2011), Professors of the National University of Life and Environmental Sciences of Ukraine Volodymyr Hudz (2011), Semen Tanchyk (2016) and others it is established that in each field, depending on the culture and ecological conditions of a particular year, there are from ten to hundreds of species of weeds. However, to develop measures and methods to control their numbers in agrocenoses, it is necessary to focus not on individual weed species, but on the set of their dominant representatives and the survey database based on IT technologies (global database GloNAF (Global Naturalized Alien Flora), EPPO Databases, etc.)

The set of weed species with certain biological properties and sensitivity to herbicides, which require appropriate control measures, is a type of weediness. Based on the species composition of weeds, which is specific to the conditions of a particular agro-climatic zone, there are five simple types of weediness:

a) annual cereal type (spring weeds of the cereal family);

b) dicotyledonous-annual type (spring, winter and biennial weeds of the dicotyledonous class);

c) root-sprout type (root-sprouting and some rhizomatous weeds of the dicotyledonous class);

d) tap-roote type (Taraxacum officinalis and other tap-rooted species);

e) type of Elytrigia.

Simple types of weeds are usually found in only a third of the fields. Mostly complex types dominate - from 2-3 simple ones. Annual-cereal, dicotyledonous-annual and root-sprout types and their combinations account for approximately $98 \%$ of all weed types characteristic of the Forest-Steppe zone.

Compared to coenoses of other crops, potato crops have more favorable conditions for weed growth and development. Cereals, increasing the vegetative mass, completely cover the soil surface and shade the plants, reducing the access of sunlight to them. Under such conditions, segetal species are suppressed. In row crops, a large area of the soil surface is illuminated for a long period of time, which provokes the growth and development of weeds.

Unlike many other field crops, specialized weeds do not develop in potato crops. The initial intensive weed infestation of the agrocenosis begins with the period of planting potatoes and lasts until the closure of the tops in rows. The wide aisles during this period are practically not shaded by stems, and under these conditions weeds quickly capture the territory, suppressing the seedlings of potato. 
The next period of intense weed infestation is manifested with the beginning of the death of potato stalks or their mowing. Where the soil surface becomes open, weeds receive sufficient light and begin to actively develop.

\section{MATERIAL AND METHODS}

The study was carried out during the 2015-2019 on a dark gray podzolozhennym midloamy soil of the research field of the Cience Research Center of Lviv National Agrarian University.

The arable layer $(0-30 \mathrm{~cm})$ is characterized by the following agrochemical parameters:

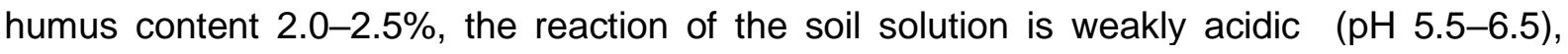
hydrolytic acidity $2.0-4.2 \mathrm{mg}-\mathrm{eq} / 100 \mathrm{~g}$ of soil, the degree of saturation of the bases of $75-90 \%$, $\mathrm{N}$ (according to Cornfield) $-51.2 \mathrm{mg} / \mathrm{kg}$ of soil, P2O5 (according to Chirikov) - $92 \mathrm{mg} / \mathrm{kg}$ of soil and K2O (according to Maslova) $-107 \mathrm{mg} / \mathrm{kg}$ of soil.

The actual weed infestation was determined in the main phases of the growing season and before the harvesting of the crop at the fixed accounting sites of $0.25 \mathrm{~m}$ in 4 places of each repetition of the variant, where the number of weed plants (in units $/ \mathrm{m}^{2}$ ) was counted. During the weed count, quantitative and species accounting of weeds, sampling, description, and data generation of varying degrees of weed development were performed.

The study was performed in a two-factor experiment using potatoes of the regional variety of intensive type Volia (selection of scientists of Lviv National Agrarian University in Dublyany).

Factor $\mathbf{A}$ is the use of herbicides as a method of weed control, in which herbicides with different mechanisms of action were applied in potato crops - soil herbicides before the emergence of crop plants and post-emergence - in the budding phase at plant heights of $10-15 \mathrm{~cm}$.

The experiment used the following scheme of herbicide use:

1. Control (without the use of herbicide).

2. Zencor Liquid, $1 \mathrm{l} / \mathrm{ha}+$ Titus, $50 \mathrm{~g} / \mathrm{ha}$.

3. Zencor Liquid, $1 \mathrm{l} / \mathrm{ha}+$ Titus, $30 \mathrm{~g} / \mathrm{ha}+$ through 8 days Titus, $20 \mathrm{~g} / \mathrm{ha}$.

4. Gesagard, 4 I/ha + Panthera, 1 I/ha.

Factor B - fertilizer system: on organic and organo-mineral backgrounds.

Under the organo-mineral system, fertilizers were applied to potatoes in autumn - $60 \mathrm{t} / \mathrm{ha}$ of manure and in spring $-4 \mathrm{c} / \mathrm{ha}$ of nitroammophoska ( $\mathrm{N}: \mathrm{P}: \mathrm{K}=16: 16: 16)$.

Under the organic fertilizer system $-50 \mathrm{t} / \mathrm{ha}$ of manure $+180-200 \mathrm{c} /$ ha of white mustard per siderate.

\section{RESULTS AND DISCUSSION}

In the Forest-Steppe zone, a large variety of weeds grows. This feature is due to the fact that the Forest-Steppe is a transitional climatic zone, where there are both typical representatives of the flora of the zone of sufficient moisture (especially in the north-western part of the Forest-Steppe) and representatives of the vegetation of the Steppe zone. 
According to the results of the study during 2015-2019, we identified different types of weeds in the agrophytocenosis of potatoes. Among them, 10 species of widespread weeds were identified, namely: Galinsoga parviflora Cav., Chenopodium album L., Amaranthus retroflexus L., Echinocloa crus-galli L., Agropyron repens L., Equisetum arvense L, Setaria glauca L., Sonchus oleraceus L., Polygonum convolvulus L., Thlaspi arvense L.

The use of herbicides in the variants of the experiment with different fertilization systems affected the total number of weeds and their ratio in the structure of weeds in the potato agrocenosis. It was found that the organo-mineral system of fertilizers forms a mixed type of weeds, the largest share among annual weeds on average over the years of study were Amaranthus retroflexus - 21\%, Chenopodium album -15\%, Polygonum convolvulus - 13\%, Galinsoga parviflora - 9\%, Echinochloa crus-galli L. - 8\%. The share of perennial root-sprout weeds was represented mainly by Sonchus oleraceus L. $-7 \%$.

The biological group of perennial rhizome weeds, which accounted for $14 \%$, consisted mainly of Elytrigia repens L. and Equisetum arvense L. (Fig. 1).
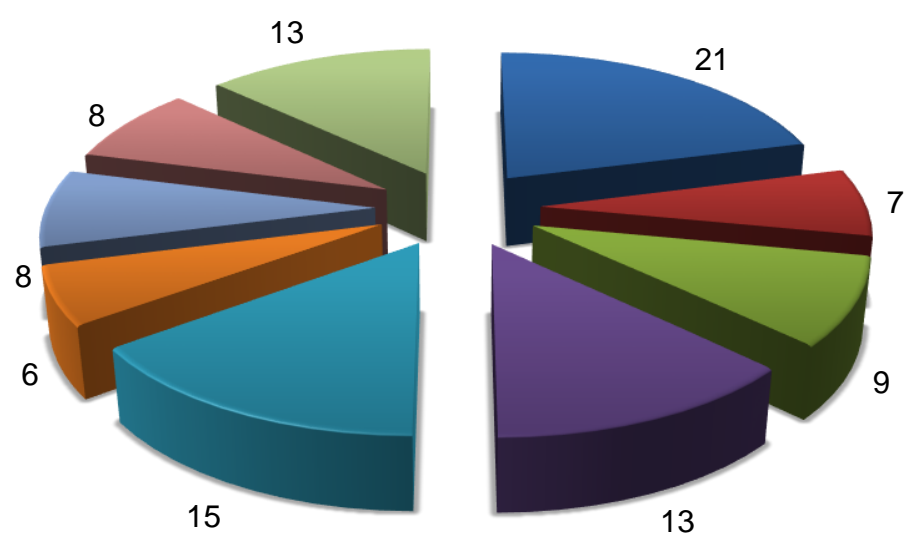

$\square$ Amaranthus retroflexus

- Sonchus oleraceus

$\square$ Galinsoga parviflora

- Polygonum convolvulus

$\square$ Chenopodium album

$\square$ Equisetum arvense

$\square$ Echinochloa crus-galli

$\square$ Elytrigia repens

$\square$ Others

Fig. 1. Species composition of weeds in the potato agrocenosis of at harvesting under organo-mineral fertilizer system $\left[\mathrm{pcs} / \mathrm{m}^{2}\right]$ (average for 2015-2019)

Under the organic system of fertilization and application of herbicides in the agrophytocenosis of potato, perennial weeds such as Sonchus oleraceus L. and Equisetum arvense L. practically fall out, but the number of annual weeds increases: Chenopodium album on average 15-0 pcs $/ \mathrm{m}^{2}$, Polygonum convolvulus L. - by $5-10 \mathrm{pcs} / \mathrm{m}^{2}$, Amaranthus retroflexus by $8-13 \mathrm{pcs} / \mathrm{m}^{2}$, Thlaspi arvense - by $4-6 \mathrm{pcs} / \mathrm{m}^{2}$, that is a dicotyledonous-annual type of weediness is formed (Fig. 2).

It was found that the lowest weediness in potato crops under the organo-mineral fertilizer system on average over the years of the research was formed in the variant of application of herbicides Gezagard $4 \mathrm{l} / \mathrm{ha}+$ Panthera $1 \mathrm{l} / \mathrm{ha}$. At the time of harvest it was $20 \mathrm{pcs} / \mathrm{m}^{2}$, which is $81 \%$ less the control variant $-102 \mathrm{pcs} / \mathrm{m}^{2}$. 


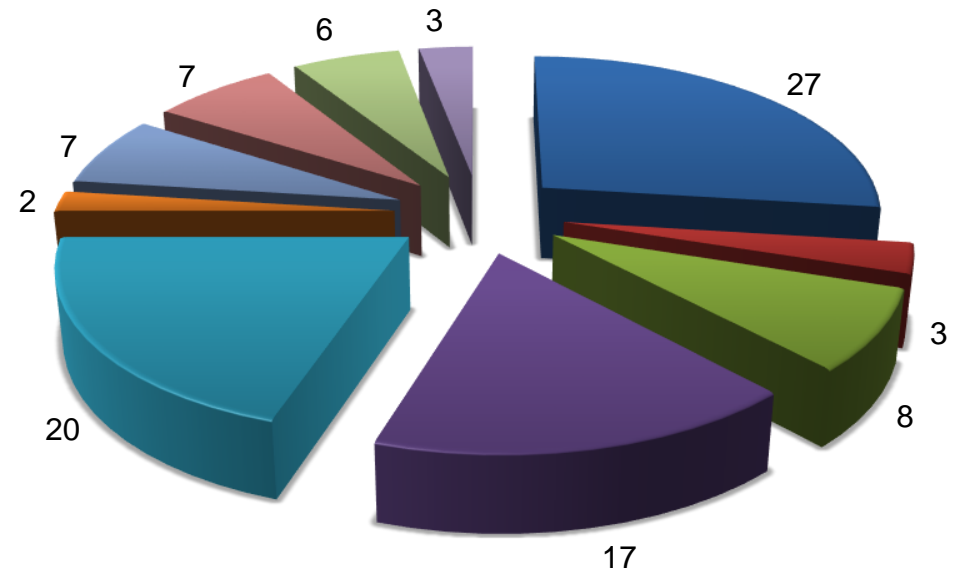

17
- Amaranthus retroflexus

๑Sonchus oleraceus

$\square$ Galinsoga parviflora

DPolygonum convolvulus

๑Chenopodium album

$\square$ Equisetum arvense

$\square$ Echinocloa crus-galli

$\square$ Elytrigia repens

$\square$ Thlaspi arvense

$\square$ Others

Fig. 2. Species composition of weeds in the potato agrocenosis of at harvesting under the organic fertilizer system $\left[\mathrm{pcs} / \mathrm{m}^{2}\right.$ ] (average for 2015-2019)

It was found that the lowest weediness in potato crops under the organo-mineral fertilizer system on average over the years of the research was formed in the variant of application of herbicides Gezagard $4 \mathrm{l} / \mathrm{ha}+$ Panthera $1 \mathrm{l} / \mathrm{ha}$. At the time of harvest it was $20 \mathrm{pcs} / \mathrm{m}^{2}$, which is $81 \%$ less the control variant $-102 \mathrm{pcs} / \mathrm{m}^{2}$.

The lowest weediness in potato crops under the organic fertilizer system on average over the years of research was formed in the variant of application of herbicides Gezagard 4 I/ha + + Panthera $1 \mathrm{l} / \mathrm{ha}$, where at the time of harvest it was $36 \mathrm{pcs} / \mathrm{m}^{2}$, which $67 \%$ less compared to the control variant $\left(109 \mathrm{pcs} / \mathrm{m}^{2}\right)$.

Herbicide control of weeds in the agrocenosis of the crop influenced the formation of potato yields. Favorable conditions for the growth and development of the potato agrocenosis have allowed weeds to effectively absorb nutrients and compete with cultivated plants and, consequently, reduce their productivity (Table 2).

Table 2. Yield of tubers of potato variety Volia by organo-mineral / organic fertilizer systems [t/ha]

\begin{tabular}{|c|c|c|c|c|c|c|c|}
\hline \multirow{2}{*}{ A variant of the experiment } & \multicolumn{5}{|c|}{ Year } & \multirow{2}{*}{$\begin{array}{c}\text { Average } \\
\text { for } \\
2015-2019\end{array}$} & \multirow{2}{*}{$\begin{array}{l}\text { Gain to } \\
\text { control } \\
{[\%]}\end{array}$} \\
\hline & 2015 & 2016 & 2017 & 2018 & 2019 & & \\
\hline $\begin{array}{l}\text { 1. Control (without the use } \\
\text { of herbicide) }\end{array}$ & $\begin{array}{l}21,1 / \\
20,8\end{array}$ & $\begin{array}{l}21,8 / \\
21,1\end{array}$ & $\begin{array}{l}20,9 / \\
20,2\end{array}$ & $\begin{array}{l}21,9 / \\
21,0\end{array}$ & $\begin{array}{r}21,6 / \\
19,7\end{array}$ & $\begin{array}{l}21,5 / \\
20,6\end{array}$ & - \\
\hline $\begin{array}{l}\text { 2. Zencor Liquid, } 1 \mathrm{l} / \mathrm{ha}+\text { Titus, } \\
50 \mathrm{~g} / \mathrm{ha}\end{array}$ & $\begin{array}{l}26,0 / \\
24,8\end{array}$ & $\begin{array}{l}26,8 / \\
25,0\end{array}$ & $\begin{array}{l}26,2 / \\
25,1\end{array}$ & $\begin{array}{l}26,5 / \\
25,1\end{array}$ & $\begin{array}{l}26,3 / \\
25,4\end{array}$ & $\begin{array}{l}26,4 / \\
25,1\end{array}$ & $\begin{array}{c}+22,8 / \\
21,9\end{array}$ \\
\hline $\begin{array}{l}\text { 3. Zencor Liquid, } 1 \mathrm{l} / \mathrm{ha}+\text { Titus, } \\
30 \mathrm{~g} / \mathrm{ha}+\text { through } 8 \text { days Titus, } \\
20 \mathrm{~g} / \mathrm{ha}\end{array}$ & $\begin{array}{l}26,9 / \\
25,1\end{array}$ & $\begin{array}{l}26,5 / \\
25,3\end{array}$ & $\begin{array}{l}26,6 / \\
25,1\end{array}$ & $\begin{array}{l}27,0 / \\
25,5\end{array}$ & $\begin{array}{l}26,9 / \\
25,4\end{array}$ & $\begin{array}{l}26,8 / \\
25,3\end{array}$ & $\begin{array}{c}+24,7 / \\
22,9\end{array}$ \\
\hline 4. Gesagard, $4 \mathrm{I} / \mathrm{ha}+$ Panthera, $1 \mathrm{l} / \mathrm{ha}$ & $\begin{array}{l}26,8 / \\
25,4\end{array}$ & $\begin{array}{l}26,7 / \\
24,9\end{array}$ & $\begin{array}{l}26,9 / \\
25,4\end{array}$ & $\begin{array}{l}27,1 / \\
25,8\end{array}$ & $\begin{array}{l}26,8 / \\
25,4\end{array}$ & $\begin{array}{l}26,9 / \\
25,4\end{array}$ & $\begin{array}{c}+25,2 / \\
23,3\end{array}$ \\
\hline
\end{tabular}


It is important to note that over the years of research in products - potato tubers the residual amount of active substances of herbicides did not exceed the MPC.

Thus, in the agrocenosis of potatoes of the Volia variety due to the use of Gerzagard (4 I/ha) and Panthera (1 l/ha) herbicides in the experimental variants, the highest yield is formed: under the organo-mineral fertilizer system $-26.9 \mathrm{t} / \mathrm{ha}(+25.2 \%$ to control), and under organic -25.4 t/ha ( $+23.3 \%$ to control).

The fertilizer system is an important agronomic measure in the technology of growing potato tubers - it creates optimal conditions for the growth and development of cultivated plants in the agrocenosis and the formation of higher resistance to weeds, reducing their harmfulness. At the same time, the application of organic fertilizers increases weeds infestation and changes the quantitative and species composition of weeds in the potato agrocenosis.

\section{CONCLUSIONS}

Potentially dangerous species in agrocenoses are and will be adventitious plants, which will have high and medium competitiveness, and the total harmfulness and distribution area will cover the main areas of cultivation of crops in Ukraine.

It has been established that the fertilization system has an effect on the state of weeds infestation and the formation of dominant weed species, and, consequently, on the types of weediness of the agrophytocenosis of potato.

In the potato agrocenosis under the organic fertilizer system was dominated by biological groups of annual weeds compared to the organo-mineral system.

Weed control of potato agrocenosis according to the scheme of sequential application of herbicides Gezagard at a rate of $4 \mathrm{l} / \mathrm{ha}$ and Panthera $-1 \mathrm{l} / \mathrm{ha}$ reduces the number of weeds by $81 \%$ for organo-mineral fertilizer system and $67 \%$ for organic system compared to control.

The use of Gerzagard (4 I/ha) and Panthera ( $1 \mathrm{l} / \mathrm{ha}$ ) herbicides in the experimental variants allows to obtain the highest yield of tubers - on average 26.9 t/ha ( $+25.2 \%$ to control) and $25.4 \mathrm{t} / \mathrm{ha}(+23.3 \%$ to control) for both fertilizer systems, respectively.

\section{REFERENCES}

Biernacki J. Czyste ziemniaki do wschodów. Topagrar, https://www.topagrar.pl/, access: 18.04.2018. [in Polish]

Groszyk J. 2017. Chemiczne odchwaszczanie TUZ. Farmer 4, https://www.farmer.pl/produkcja-roslinna/ochronaroslin/chemiczne-odchwaszczanie-tuz,70472.html, access: 18.04.2018. [in Polish]

Gutyansky R.A., Zuza V.S., Fesenko A.M. 2017. Metodychni vkazivky dlya vykonannya praktychnoyi roboty z dystsypliny "Osnovy ahronomiyi" "Metody otsinky herbolohichnoyi sytuatsiyi na poli". KNTUA, Kharkiv. [in Ukrainian]

Hryhorak M.YU., Protopopova V.V., Shevera M.V. 2004. Aspekty ekonomichnoyi otsinky vplyvu neaboryhennykh roslyn Ukrayiny na dovkillya [Aspects of economic assessment of the impact of non-native plants of Ukraine on the environment]. Rehionalni perspektyvy 6, 44-48. [in Ukrainian]

Ivashchenko O.O., Ivashchenko O.O. 2019. Zahalna herbolohiya. NAAS, Institute of Bioenergy Crops and Sugar Beets, Kyiv. [in Ukrainian]

Ivashchenko O.O. 2004. Suchasni problemy herbolohiyi [Modern problems of herbology]. Visnyk ahrarnoyi nauky 3, 27-29. [in Ukrainian] 
Ivashchenko O.O. 2004. Vazhlyvyy faktor diyi herbitsydiv, in: Weed problems and ways to reduce arable land weeding. Proceedings of 4th scientific-theoretical conference of Ukrainian Scientific Society of Herbologists, Kyiv 3-4 March 2004, Ukrainian Scientific Society of Herbologists, Kyiv, Koloobih, 155-161. [in Ukrainian]

Ivashchenko 0.0. 2009. Prima dopomozhe realno [Prima will really help]. Ahrobiznes s'ohodni 8, 16. [in Ukrainian]

Kurdyukova O.M. 2011. Zasmichenist posiviv sivozminy v zalezhnosti vid obrobitku gruntu [Weed infestation of crop rotation crops depending on tillage]. Visnyk Poltavskoyi derzhavnoyi ahrarnoyi akademiyi 1, 51-54. [in Ukrainian]

Man'ko YU.P. 2009. Efektyvnist kontrolyu zabur'yanenosti posiviv lanky sivozminy zalezhno vid ekolohizatsiyi zemlerobstva $v$ Lisostepu [Efficiency weed control of crops of crop rotation link depending on ecologing of agriculture in the Forest-Steppe]. Karantyn i zakhyst roslyn 2, 21-23. [in Ukrainian]

Protopopova V.V., Mosyakin S.L., Shevera M.V. 2002. Fitoinvaziyi v Ukrayini yak zahroza bioriznomanittyu: suchasnyy stan i zavdannya na maybutnye. Institute of Botany M.G. Kholodnogo NAS of Ukraine, Kyiv. [in Ukrainian]

Quarantine Pests for Europe. 1997. 2nd edition. Cab international in association with the European and Mediterranean Plant Protection Organization (EPPO). Egham, UK.

Suchorzewski R. 2018. Pole ziemniaka wolne od chwastów. Crop Sci. Pol., https://www.agro.bayer.com.pl/ /co-nowego/pole-ziemniaka-wolne-od-chwastow. [in Polish]

Shuvar I.A. 2007. Herbolohiya: Terminolohichnyy slovnyk-dovidnyk. Aral, Lviv. [in Ukrainian]

Shuvar I.A. 2008. Ekolohichni osnovy znyzhennya zaburyanenosti ahrofitotsenoziv. Novyy Svit, Lviv. [in Ukrainian]

Shuvar I.A., Boyko I.Y.E. 2011. Osoblyvosti zminy tsenozu buryaniv u korotkorotatsiyniy sivozmini Zakhidnoho Lisostepu Ukrayiny [Peculiarities of weed coenosis change in short-rotation crop rotation of the Western ForestSteppe of Ukraine]. Naukovyy visnyk NUBiP Ukrayiny 162, 27-34. [in Ukrainian]

Shuvar I.A., Gudz V.P., Shuvar A.M., Krushyns'kyy O.P. 2011. Ekoloho-herbolohichnyy monitorynh i prohnoz v ahrotsenozakh. Ukrainski tekhnolohiyi, Lviv. [in Ukrainian]

Shuvar I.A., Korpita H.M. 2016. Osoblyvosti zaburyanennya ahrotsenoziv yachmenyu yaroho i kartopli zalezhno vid zastosuvannya herbitsydiv [Features of weed infestation agrocenoses of spring barley and potatoes depending on the use of herbicides]. Sci. Rise 9/1 (26), 39-43. [in Ukrainian]

Shuvar I.A., Korpita H.M. 2016. Vplyv elementiv tekhnolohiyi vyroshchuvannya na zaburyanenist ta produktyvnist yachmenyu yaroho i kartopli [Influence of elements of cultivation technology on weediness and productivity of spring barley and potatoes]. Zbirnyk naukovykh prats natsionalnoho naukovoho tsentru "Instytut zemlerobstva NAAN" 3-4, 71-81. [in Ukrainian]

Shuvar I., Korpita H., Binert B., Boyko I. 2019. Formuvannya herbolohichnoho stanu ahrotsenozu korotkoyi rotatsiyi Zakhidnoho Lisostepub Ukrayiny [Formation of the herbological state of the short-rotation agrocenosis of the Western Forest-Steppe of Ukraine]. Visnyk LNAU 23, 97-102, https://doi.org/10.31734/ lagronomy2019.01.097. [in Ukrainian]

Storchous I.M. 2010. Monitorynh sehetalnoyi roslynnosti [Monitoring of segetal vegetation]. Ahrobiznes sohodni 23, 32-34. [in Ukrainian]

Sykalo 0.O., Cherneha T.O. 2017. Karantynni buryany. Kyiv, [b.w.]. [in Ukrainian]

Tanchyk S.P. 2016. Efektyvnist kontrolyu buryaniv u posivakh kukurudzy za riznykh system osnovnoho obrobitku gruntu v pravoberezhnomu lisostepu Ukrayiny [The effectiveness of weed control in maize crops under different systems of basic tillage in the right-bank forest-steppe of Ukraine]. Visnyk Poltavskoyi derzhavnoyi ahrarnoyi akademiyi 4, 20-24. [in Ukrainian]

Urbanowicz J. 2015. Chwasty eliminuj przed wschodami ziemniaka. Agropolska.pl, https://www.agropolska.pl. [in Polish]

Zarzecka K. 2015. Odchwaszczanie plantacji ziemniaka. Gazeta Rolnicza "Nasza Rola", https://naszarola.pl/ /zwalczanie-chwastow-na-plantacjach-ziemniakow/. [in Polish]

Zuza V.S. 2014. Do pytannya poshyrenosti buryaniv [To the question of weed prevalence]. Scientific works of the Institute of Bioenergy Crops and Sugar Beets 20, 41-46. [in Ukrainian] 